\title{
Maternal concerns in the postpartum period: an integrative review
}

\author{
Preocupaçóes maternas no pós-parto: revisão integrativa \\ Preocupaciones maternas en el posparto: revisión integradora
}

Ana Bela de Jesus Roldão Caetano*; Isabel Margarida Marques Monteiro Dias Mendes**; Zaida de Aguiar Sá Azeredo Rebelo***

\begin{abstract}
Background: The postpartum period is a particularly relevant area when caring for the woman/couple and family. Thus, the mothers' concerns during the transition to parenthood can have a differential impact on the adaptation to the new parental role.

Objective: To identify the main maternal concerns in the postpartum period.

Methodology: Integrative review in the CINAHL (Plus with Full Text), MEDLINE (with Full Text), MedicLatina (tm), Cochrane (Plus Collection), and Nursing \& Allied Health Collection (tm) databases on the EBSCOhost platform. Seventeen studies were selected which had been published between 1990 and 2016 in Portuguese and English.

Results: Six dimensions were identified which reflect maternal concerns during the postpartum period: maternal concerns and infant care; maternal concerns and functional recovery; maternal concerns and transition to parenthood; maternal concerns and marital relationship; maternal concerns and family/social support; and maternal concerns and support from health professionals.

Conclusion: The review synthesizes the evidence on maternal concerns which may lead to the development of strategies for increasing maternal competence during the transition to parenthood.
\end{abstract}

Keywords: maternal; concerns; postpartum period

\section{Resumo}

Enquadramento: O período de pós-parto representa uma área fundamental nos cuidados à mulher/casal e família. Neste contexto, as preocupaçóes das mães durante a transição para a parentalidade podem assumir um impacto diferencial na adaptação ao novo papel parental.

Objetivo: Identificar as principais preocupaçóes maternas no período pós-parto.

Metodologia: Revisão integrativa, no motor de busca EBSCOhost, nas bases de dados CINAHL (Plus with Full Text), MEDLINE (with Full Text), MedicLatina (tm) Cochrane (Plus Collection), Nursing \& Allied Health Collection $(\mathrm{tm})$. Foram elegíveis 17 estudos no período entre 1990 e 2016, nos idiomas português e inglês.

Resultados: A análise realizada identificou 6 áreas que refletem as preocupaçóes maternas no pós-parto: preocupaçóes maternas e o cuidar do recém-nascido; preocupaçōes maternas e recuperação funcional; preocupaçôes maternas e transição para a parentalidade; preocupaçóes maternas e relacionamento conjugal; preocupaçôes maternas e família/apoio social e preocupaçóes maternas e apoio de profissionais de saúde.

Conclusão: A revisão sintetiza conhecimentos das preocupações maternas que podem ser promotoras de estratégias que aumentem a competência materna na transição para a parentalidade.

Palavras-chave: maternas; preocupaçóes; período pós-parto

*MSc., Adjunct Professor, Nursing School of Coimbra, 3046-851, Coimbra, Portugal [ana@esenfc.pt]. Contribution to the article: literature search, selection of the articles for the integrative review, and article writing. Address for correspondence: Urbanização Cruz Vale do Seixo, lote 8, 3020-085, Coimbra.

**Ph.D., Coordinating Professor, Nursing School of Coimbra, 3046-851, Coimbra, Portugal [isabelmendes@esenfc.pt]. Contribution to the article: revision of the selected articles, elaboration of the article table, and final revision.

****Ph.D., Guest Lecturer (retired), ICBAS, University of Porto, 4050-313, Porto [zaida.reci@ gmail.com]. Contribution to the article: revision of the selected articles and final revision.

\section{Resumen}

Marco contextual: El período de posparto representa un área fundamental en los cuidados a la mujer/pareja y familia. En este contexto, las preocupaciones de las madres durante la transición a la parentalidad pueden tener un impacto diferencial en la adaptación al nuevo papel parental.

Objetivo: Identificar las principales preocupaciones maternas en el período de posparto.

Metodología: Revisión integradora, en el motor de búsqueda EBSCOhost en las bases de datos CINAHL (Plus with Full Text), MEDLINE (with Full Text), MedicLatina (tm), Cochrane (Plus Collection), Nursing \& Allied Health Collection (tm). Del total, 17 estudios fueron elegibles entre 1990 y 2016, en portugués y en inglés.

Resultados: El análisis realizado identificó 6 áreas que reflejan las preocupaciones maternas en el posparto: preocupaciones maternas y cuidado del recién nacido; preocupaciones maternas y recuperación funcional; preocupaciones maternas y transición hacia la parentalidad; preocupaciones maternas y relación conyugal; preocupaciones maternas y familia / apoyo social; y preocupaciones maternas y apoyo de profesionales de la salud.

Conclusión: La revisión sintetiza conocimientos de las preocupaciones maternas que pueden promover estrategias que aumenten la competencia materna en la transición a la parentalidad.

Palabras clave: maternas; preocupaciones; periodo posparto

Received for publication: 21.09.2017

Accepted for publication: 02.05 .2018

Série IV - n. ${ }^{\circ} 17$ - ABR./MAI./JUN. 2018 


\section{Introduction}

In today's society, due to women's increasing participation in the job market, having a child can have a significant impact, particularly on women's feelings towards motherhood (Mendes, 2009).

The postpartum period is a particularly relevant area when caring for the woman/couple and family. In this period, specialized maternal health and obstetric nursing interventions, based on the knowledge about the mothers' concerns, are important for the promotion of a healthy transition both for the mothers, the couple, and the infants. According to Kaitz (2007), parental concerns are part of a set of relational behaviors that occur when children are born and extend throughout the parents' life, with greater or lesser intensity, involving something more than the parents caring for their child. Therefore, parental concerns have a historical, cultural, and contextual dimension, in which the characteristics of the child, parents, social group, and historical period are important. The concept of primary maternal preoccupation was first used in the 1950s by Winnicott (2014) to designate a woman's state of concern during the first weeks or months after childbirth, which may have already started at the end of pregnancy. Maternal concerns reflect the mothers needs in the transition to the postpartum period, as well as the changes related to taking on new roles and redefining/reorganizing responsibilities within the parental/family dyad. Their different concerns during the period of transition to parenthood can have a differential impact on the adaptation to the new parental role.

According to Kaitz (2007), mothers' concerns about their infant can be interpreted from a positive and a negative perspective. From the positive perspective, it contributes to keeping mothers more focused on and physically closer to their infant, thus providing timely responses to their infant's needs and increasing the mother-infant bond. On the other hand, intense and obsessive maternal concerns can be distressful and impair mothers' capacity to make decisions and solve problems. Mothers who are overly insecure about infant care have a greater risk of developing obsessive-compulsive disorders and depression, which will interfere with their ability to connect with their infant.

The objective of this integrative review is to identify the main maternal concerns in the postpartum period, thus allowing health professionals to select relevant information and make it available for new parents by using various teaching strategies to stimulate learning and retention of information.

\section{Methodological procedures of inte- grative review}

This is an integrative literature review about maternal concerns in the postpartum period. The purpose of this type of study is to select, critically appraise, and synthesize the available evidence on a given topic. Despite being a more comprehensive research method than other methods, it also requires methodological rigor in all its stages (Mendes, Silveira, \& Galvão, 2008).

Based on Mendes et al. (2008), the following steps were applied in this integrative review: identifying the topic and formulating the guiding question, establishing the criteria for inclusion and exclusion of studies and search in the relevant literature, selecting the information to be extracted from the selected studies, interpreting the results, and presenting the review/synthesis of knowledge.

The inclusion criteria took into account the target population, that is, primiparous and multiparous women (using synonyms such as mothers and first-time mothers), the concept of interest, that is, maternal concerns, and the design, that is, qualitative, quantitative, and mixed-method studies. As an inclusion criterion, this review also considered scientific publications in scientific journals with free access to full-text in online databases (in addition to the paper support), as a principle of accessibility and equity in research and to all researchers.

The following exclusion criteria were applied: review studies, editorials, opinions/comments, dissertations and doctoral theses in a repository.

The search covered the time period between January 1990, when studies were published in scientific journals related specifically to maternal concerns, and December 2016, when the integrative review was conducted. When this article was revised in June 2017, a new search was performed but no chances were made.

The search was conducted in the EBSCOhost 
platform using the following databases: CINAHL (Plus with Full Text), MEDLINE (with Full Text), MedicLatina (tm), Cochrane (Plus Collection), and Nursing \& Allied Health Collection (tm). In this search, given the lack of other MeSH or DeCS descriptors, the descriptor/medical subject heading $(\mathrm{MeSH})$ postpartum was combined with the operator "AND" and the keywords maternal and concerns were used.

The term puerperium was also used as a synonym for postpartum, combined with the previous keywords. No results were obtained, for which reason the term postpartum was the only one used. The same search strategy was used in all databases based on the above-mentioned criteria.

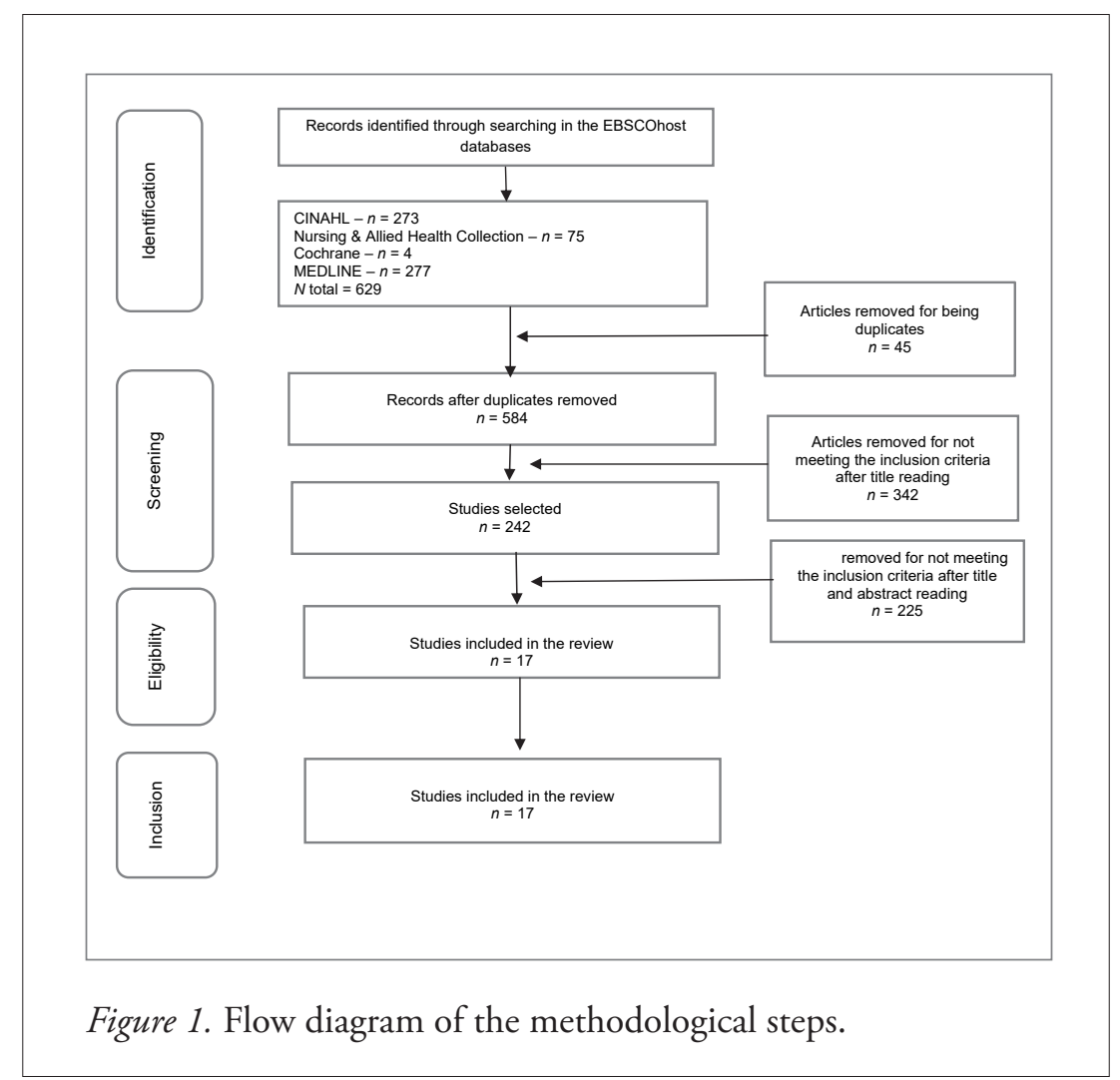

As shown in Figure 1, 17 articles were found: quantitative descriptive-correlational studies (6) and clinical trial (1); qualitative studies (8); and mixed-method studies (2).

After application of the inclusion and exclusion criteria, the studies selected for this integrative review were appraised taking into account the consistency between the objectives set out and the relevance of the research design (Mendes et al., 2008).

A specific form was designed to collect information from the selected articles, which included the name of the study, type of publication, study design, objectives, sample, and main results. The presentation of the review and the discussion of data were carried out in a descriptive manner in order to allow for the interpretation of the results, and, consequently, the review/synthesis of knowledge.

\section{Results and interpretation}

Table 1 shows the studies selected for this integrative review.

As shown in Table 1, 17 articles were found: quantitative descriptive-correlational studies (6) and clinical trial (1); qualitative studies (8); and mixed-method studies (2). 
Table 1

Bibliometric indicators of the studies selected for this integrative review

\begin{tabular}{llc}
\hline Study/Article & Country & Method \\
\hline S1 & & \\
Jansen, I., \& Stewart, M. (1990). Maternal concerns: what are they?. Can. Fam. & England & Qualitative \\
Physician, 36(jun), 1103-1107. & & \\
\hline
\end{tabular}

S2

Sheil, E. P., Bull, M.J., Moxon, B. E., Muehl, P. A., Kroening, K. L., Peterson-Palmberg, G., \& Kelber, S. (1995). Concerns of childbearing women: a Maternal Concerns Questionnaire as an assessment tool. JOGNN Clinical Studies,

USA Quantitative 24(2), 149-154.

S3

Fishbein, E. G., \& Burggraf, E. (1997). Early postpartum discharge: how are USA Quantitative mothers managing?. JOGNN Clinical Studies, 27(2), 142-148.

S4

Lugina, H. I., Christensson, K., Massawe, S., Nystrom, L., \& Lindmark, G. (2001).

Change in maternal concerns during the 6 weeks postpartum period: a study of

primiparous mothers in Dar Es Salaam, Tanzania. Journal of Midwifery \& Women's

Tanzania

Qualitative Health, 46(4), 248-257.

S5

Emmanuel, E., Creedy, D., \& Fraser, J. (2001). What mothers want: a postnatal Australia Qualitative survey. Australian Journal of Midwifery, 14(4), 16-20.

S6

Lugina, H. I., Nystrom, L., Christensson, K., \& Lindmark, G. (2004). Assessing mothers' concerns in the postpartum period. Journal of Advanced Nursing, 48(3),

Tanzania $\quad$ Mixed $279-290$.

S7

Kanotra, S., D’Angelo, D., Phares, T. M., Morrow, B., Barfield, W. D., Lansky, A. (2007). Challenges faced by new mothers in the early postpartum period: An analysis of comment data from the 2000 Pregnancy Risk Assessment Monitoring USA Qualitative System (PRAMS) Survey. Matern Child Health J., 11, 549-558.

S8

Kaitz, M. (2007). Maternal concerns during early parenthood. Child: care, health Jerusalem Quantitative and development, 33(6), 720-727.

S9

Conde, A., \& Figueiredo, B. (2007). Preocupações de mães e pais, na gravidez, Portugal Quantitative parto e pós-parto. Análise Psicológica, 3(XXV), 381-398.

S10

Weiss, M., Fawcett, J., \& Abe, C. (2009). Adaptation, postpartum concerns, and learning needs in the first two weeks after caesarean birth. Journal of Clinical Nurs-

Mixed ing, 18, 2938-2948.

S11

Osman, H., Chaaya, M., Zein, L. M., Naassan, G., Wick, L. (2010). What do first-time mothers worry about? A study of usage patterns and content of calls

Lebanon Quantitative made to a postpartum support telephone hotline. BMC Public Health, 10, 1-6. 
S12

Salonen, A. H., Oommen, H., \& Kaunonen, M. (2014). Primiparous and multiparous mothers' perceptions of social support from nursing professionals in postna-

Finland Quantitative tal wards. Midwifery, 30, 476-485.

S13

Martin, A., Horowitz, C., Balbierz, A., \& Howell, E. A. (2014). Views of women and clinicians on postpartum preparation and recovery. Matern Child Health J.,

USA Qualitative 18, 707-713.

S14

Ong, S. F., Chan, W. S., Chong, Y. S., Shorey, S., Klainin-Yobas, P., He, H. (2014). First-time mothers' postnatal experiences and support needs in Singapore: Singapura Qualitative a descriptive qualitative study. Midwifery, 30(6), 772-778.

\section{S15}

Liu, Y. Q., Petrini, M., \& Maloni, J. A. (2015). "Doing the month”: postpartum China Qualitative practices in Chinese women. Nursing and Health Sciences, 17, 5-14.

\section{S16}

Edhborg, M., Nasreen, H., \& Kabir, Z. N. (2015). “I can't stop worrying about everything" -Experiences of rural Bangladeshi women during the first postpartum months. International Journal of Qualitative Studies on Health and Well-being, 10, $1-9$.

S17

Hannan, J., Brooten, D., \& Youngblut, J. M. (2016). Comparing mothers' postpartum concerns in two clinical trials 18 years apart: mother's postpartum concerns in two clinical trials. Journal of the American Association of Nurse Practitioners, USA Clinical Trial 28(11), 604-611.

Table 2 was designed to synthesize the information and facilitate consultation. It includes

the study identification, the population/sample, and the main results.

Table 2

Synthesis of the studies included in the integrative review

\begin{tabular}{lll}
\hline Study $\quad$ Population/Sample & Main results \\
\hline S1 & $\begin{array}{l}\text { Fuerperal women }(n=84) \\
\text { cantly more than experienced mothers: "extended crying spells"; } \\
\text { "feeling insecure about doing things right for the baby"; "get- } \\
\text { ting angry at the baby"; "bathing the baby"; and "conflicting } \\
\text { advice from friends and relatives". } \\
\text { The age of the baby markedly influenced the nature of the five } \\
\text { most common concerns. }\end{array}$ \\
\hline S2 & $\begin{array}{l}\text { Pregnant and puerperal women } \\
(n=187)\end{array}$ & $\begin{array}{l}\text { Of the study of the subscales, the most evident one was the } \\
\text { subscale Self. } \\
\text { The major concern was with the return of the figure to normal. }\end{array}$ \\
\hline Puerperal women in the first two days & $\begin{array}{l}\text { The concerns during the early postpartum period related to per- } \\
\text { ineal sutures, breast care, body image, and fatigue. } \\
\text { Need for a nursing home visit in the first week postpartum. }\end{array}$ \\
\hline
\end{tabular}


Maternal concerns at 1 week with the newborn: eyes, respiration, temperature, safety, and crying; self-care concerns: swollen perineum, and feeling tired and nervous. Need for information: preventing hemorrhage and infection and taking care of the perineum, breasts, and nipples.

Maternal concerns at 6 weeks with the newborn: crying and self-care concerns; marital relationship.

S5 Puerperal women $(n=151)$

Cohort of puerperal women and a

S6 follow-up at 1 week $(n=110)$ and 6 weeks $(n=83)$ after childbirth

Need for specific information about mothering, the creation of a restful environment, adequate pain relief, practical assistance, education, and set visiting times.

Baby-related topics: care of the baby's cord, bathing, and abdominal colic.

Mother-related topics: sore perineum, abdominal pain/cramps, breasts and nipples, tiredness, nutrition, family planning, resumption of menstruation and resumption of sex.

From the comments on postpartum concerns $(n=366)$, the following six themes were identified: (1) perceived need for social support following hospital discharge (32\%), (2) breastfeeding issues $(23.5 \%)$, (3) lack of education about how to care for the

Puerperal women at 2 and 9 months newborn after hospital discharge (21\%), (4) need for help with postpartum depression (9.5\%), (5) perceived need for extended postpartum hospital stay (8\%), and (6) need for maternal postpartum health insurance $(6 \%)$. The most common themes were the need for social support, help with breastfeeding, information on newborn care, and help with postpartum depression.

Six dimensions of concerns emerged from the questionnaire: Family Health, Return to Work, Mother's Well-being, Relationships/Support, Infant Care, and Spouse.

Primiparous women at 3 and 6 months postpartum $(n=366)$

Return to work and family health were of most concern at the $3^{\text {rd }}$ month that at the $6^{\text {th }}$ month postpartum.

Infants' (difficult) temperament and the hours working outside the house were (positively) related to mothers' concern scores.

S9 Pregnant women and their partners $(n=250)$

Mothers and fathers' concerns reveal identical stability over time, except for adverse life events concerning to family and interpersonal context and to the present pregnancy, which decrease over pregnancy and postpartum period.

Àt 2 weeks postpartum, women gave more importance to the functional and social adaptation than to the physical and emotional adaptation. Health education was the most commonly reported intervention strategy in the postpartum period.

In this sample, $24 \%$ of mothers used the hotline, of whom $60 \%$ called more than once. All callers reported that they were satis-

Puerperal women in the first 4 to 6 fied with the service. weeks postpartum $(n=353)$

Of the questions related to mothers, $66 \%$ were about breastfeeding, $60 \%$ were about infant routine care, and 23\% were about excessive crying.

The following findings should be highlighted:

Primiparous: Parenting self-efficacy, mother's age, and infant age explained $54.0 \%$ of the variation in SSNP (social support from nursing professionals).

S12 Primiparous and multiparous mothers $(n=1300)$

Multiparous: Depressive symptoms were a significant factor. Correspondingly, advice from nursing professionals, state of mind on hospital discharge and family functioning explained $49.3 \%$ of the variation in SSNP. 
Four focus groups of postpartum women $(n=45)$ and two focus groups of obstetric clinicians $(n=13)$

Four main themes were identified: lack of knowledge about postpartum, lack of preparation for the postpartum experience, lack of continuity of care, and disconnect between providers and postpartum mothers.

Results from this study indicate that many mothers do not feel prepared for the postpartum experience.

$\mathrm{S} 14$

English-speaking first-time mothers $(n=13)$ of age 21 years and above
Five themes were identified: (1) mixed emotions: anxiety, labile emotions and stress over infant care; (2) breastfeeding and physical discomfort; (3) social support; (4) cultural postnatal practice; and (5) professional support needs and continuity of care.
S15

Puerperal women in the postpartum period

"Doing the month" involves a series of practices related to the maternal role and postpartum recovery activities. There is a concern for the effect of some practices upon both maternal physical and psychological health, particularly for postpartum depression

\begin{tabular}{ll}
\hline Puerperal women $(n=21)$ with \\
depressive symptoms 2-3 months \\
postpartum
\end{tabular}

Participants: in 1997, mothers with S17 high-risk pregnancies; in 2015, firsttime mothers
At the $1^{\text {st }}$-month postpartum, the following results should be highlighted: intimate partner violence and violence in the family influenced the mothers' mental well-being.

1997 mothers were concerned with body changes, birth control, breastfeeding, maternal health problems and had more concerns about their health.

2015 mothers were concerned with not having help and fatigue. Both groups had postpartum pain concerns and problems accessing mother/infant governmental programs. The major concern regarding infant care was infant feeding.
Based on the pre-established criteria, after full-text reading and analysis of the selected studies, six dimensions were identified which reflect maternal concerns in the postpartum period: maternal concerns and infant care; maternal concerns and functional recovery; maternal concerns and transition to parenthood; maternal concerns and marital relationship; maternal concerns and family/social support; and maternal concerns and support from health professionals.

\section{Maternal concerns and infant care}

Maternal concerns with infant care are focused on several areas, including: feeding; crying; physical care; adequacy of care; other people caring for the baby; identification of signs/ symptoms of colic, illness, and behavior.

In relation to infant feeding, this maternal concern emerged in several studies (Hannan, Brooten, \& Youngblut, 2016; Kanotra et al., 2007; Lugina, Nystrom, Christensson, \& Lindmark, 2004; Osman, Chaaya, Zein,
Naassan, \& Wick, 2010; Sheil et al., 1995). These concerns relate mainly to newborns' low milk intake and breastfeeding difficulties, with the mothers requiring help from health professionals.

Another maternal concern was infant crying, namely the mothers' insecurity towards understanding infant's crying and excessive crying (Lugina, Christensson, Massawe, Nystrom, \& Lindmark, 2001; Lugina et al., 2004; Osman et al., 2010).

Physical care, the adequacy of care, and the fact that other people care for the baby were other maternal concerns related to infant care, specifically with cord care, bathing, bowels, skin, breathing, and abdominal colic (Lugina et al., 2004).

Mothers were also concerned about someone else caring for the baby, particularly in babies 10 weeks or older (Jansen \& Stewart, 1990). With regard to the identification of the signs/ symptoms of colic, illness, and behaviors, all of the studies mentioned that first-time 
mothers expressed more feelings of inadequacy associated with a lack of knowledge about infant behavior and illness signs/symptoms, referring not knowing what the baby wants or has (Jansen \& Stewart, 1990).

In a study conducted in 1995, Sheil et al. found that the mothers expressed difficulty in interpreting infant behavior and recognizing signs of illness in their infants, which was also corroborated by Lugina et al. (2001). Kaitz (2007) emphasized that mothers who have higher levels of concern are those who mentioned that the infant's temperament was difficult.

\section{Maternal concerns and functional recovery} With regard to the mothers' functional recovery in the postpartum period, this review considered the physical and emotional changes experienced during this period.

The following signs and symptoms were found in all of the analyzed studies: tiredness, fatigue, body changes and getting back to the pre-pregnancy shape, the perineum, weight, pain and discomfort, self-esteem, anxiety, and insecurity (Conde \& Figueiredo, 2007; Edhborg, Nasreen, \& Kabir, 2015; Fishbein \& Burggraf, 1997; Hannan et al., 2016; Kaitz, 2007; Lugina et al., 2001; Lugina et al., 2004; Ong et al., 2014; Weiss, Fawcett, $\&$ Abe, 2009).

\section{Maternal concerns and transition to par- enthood}

With regard to maternal concerns and transition to parenthood, the most evident aspect in the analyzed studies was the concern about being a good mother (Fishbein \& Burggraf, 1997; Jansen \& Stewart, 1990; Liu, Petrini, \& Maloni, 2015; Lugina et al., 2004).

\section{Maternal concerns and marital relationship} In the postpartum period, changes were observed in the marital relationship, that is, being parents implies an adaptation to new schedules, routines, and family dynamics. The restriction of sexual intercourse in the first weeks after childbirth (Lugina et al., 2004), the partner's behavior and the adaptation to the body changes after childbirth (Jansen \& Stewart, 1990; Lugina et al., 2001) were some of the concerns reported by the women.
The lack of time available for being a couple and interacting with one another was also evidenced in the studies by Jansen and Stewart (1990) and Fishbein and Burggraf (1997).

\section{Maternal concerns and family/social support} The majority of the selected studies mentioned maternal concerns related to the family and the social support, which means that it is a very important concern for mothers. In this regard, primiparous mothers often referred as concerns the family's behavior/acceptance of the baby and conflicting advice from friends and relatives, while multiparous women were concerned about feeling impatient with their other children (Jansen \& Stewart, 1990) and were more concerned about managing the household than primiparous women (Sheil et al., 1995).

Trends of increasing worry and decreasing confidence were observed with regard to family relationships, as well as a decrease in the confidence in relatives' reaction to the woman and the baby (Lugina et al., 2001; Lugina et al., 2004; Mendes, 2009). According to Kaitz (2007), family health and the return to work were of most concern for mothers at the $3^{\text {rd }}$ than at the $6^{\text {th }}$ month. Moreover, in the studies by Conde and Figueiredo (2007), Ong et al. (2014), and Edhborg et al. (2015), the most common maternal concerns in the transition to parenthood are the socioeconomic status, particularly the existence of financial problems and low income, as well as the professional situation (fear of becoming unemployed), the family, and interpersonal relationships (death of a relative or serious problems within the family).

Moreover, with regard to social support, a study carried out in two different years (1997 and 2015) found that the most common maternal concern in both years was the problems accessing mother/infant governmental programs to facilitate the transition to parenthood (Hannan et al., 2016).

\section{Maternal concerns and support from health professionals}

The support from health professionals in the postpartum period was shown through the need for information and health education, as well as practical assistance (Emmanuel, 
Creedy, \& Fraser, 2001; Kanotra et al., 2007; Lugina et al., 2001; Martin, Horowitz, Balbierz, \& Howell, 2014; Salonen, Oommen, \& Kaunonen, 2014; Weiss et al., 2009). After discharge, health professionals also provided support through phone calls, with an average of three calls per day and a higher volume of calls in the first four weeks after childbirth (Osman et al., 2010).

In short, in the included studies, maternal concerns related to infant care were mainly associated with infant feeding (Hannan et al., 2016; Lugina et al., 2001; Lugina et al., 2004; Kanotra et al., 2007; Osman et al., 2010; Sheil et al., 1995), followed by infant crying (Lugina et al., 2004; Osman et al., 2010), physical care (Jansen \& Stewart, 1990; Lugina et al., 2004), and, finally, the identification of signs/ symptoms of colic, illness, and behavior (Jansen \& Stewart, 1990; Kaitz, 2007; Lugina et al., 2001; Sheil et al., 1995).

With regard to maternal concerns related to functional recovery, the included studies pointed to signs of fatigue, discomfort, return to the pre-pregnancy shape, anxiety, and insecurity (Conde \& Figueiredo, 2007; Edhborg et al., 2015; Fishbein \& Burggraf 1997; Hannan et al., 2016; Kaitz, 2007; Lugina et al., 2001; Lugina et al., 2004; Mendes, 2009; Ong et al., 2014).

As for maternal concerns related to the transition to parenthood, some authors observed differences between primiparous mothers and multiparous mothers, while others stressed the mothers' concern for being a good mother (Jansen \& Stewart, 1990; Liu et al., 2015). With regard to the mothers' concerns with the marital relationship, the most common concerns were the little time available for the couple (Fishbein \& Burggraf, 1997; Jansen \& Stewart, 1990), the difficulties in adapting to the body changes, and the new family routines and dynamics (Jansen \& Stewart, 1990; Lugina et al., 2001).

In the dimension related to maternal concerns and family/social support, the main concerns were the behavior/acceptance of the baby by the family (Jansen \& Stewart, 1990; Sheil et al., 1995) and social support (for example, mother's health insurance) after hospital discharge (Conde \& Figueiredo, 2007; Edhborg et al., 2015; Hannan et al., 2016;
Kanotra et al., 2007; Ong et al., 2014).

Finally, with regard to maternal concerns and the support from health professionals in the postpartum period, the concerns highlighted were the need for information and health education and more support from some health professionals during this critical period of recovery (Emmanuel et al., 2001; Jansen \& Stewart, 1990; Lugina et al., 2001; Mendes, 2009; Salonen et al., 2014; Weiss et al., 2009). From a methodological perspective, the main limitations of this integrative review were the use of a single $\mathrm{MeSH}$ descriptor and the decision to include only studies written in Portuguese and English with free full-text access in the databases. The latter limitation was intentional, taking into account the above-mentioned principle of accessibility/equity in research and for the researchers. The fact that the studies found in the search were predominantly qualitative studies also became a limitation because it did not allow for an analysis of factors which could contribute to generating better evidence on maternal concerns.

\section{Conclusion}

The results of this integrative review made it possible to identify the main maternal concerns in the postpartum period, thereby achieving the objective of this integrative review. The following dimensions were identified in descending order of concern: maternal concerns and infant care; maternal concerns and functional recovery; maternal concerns and transition to parenthood; maternal concerns and marital relationship; maternal concerns and family/social support; and maternal concerns and support from health professionals.

In this way, the knowledge of maternal concerns becomes relevant to nursing clinical practice, namely through the provision of consistent information on parental skills and child behavior, as well as effective coping strategies that strengthen maternal competence and contribute to an adequate transition to the parental role.

Taking into account the implications for clinical practice, the authors expect to have provided a set of relevant information to the 
nurses who assume a pedagogical role in the creation, implementation, and development of strategies intended to provide a response to the main postpartum maternal concerns identified in this study.

\section{References}

Conde, A., \& Figueiredo, B. (2007). Preocupaçóes de mães e pais, na gravidez, parto e pós-parto. Análise Psicológica, 3(XXV), 381-398.

Edhborg, M., Nasreen, H., \& Kabir, Z. N. (2015). "I can't stop worrying about everything” - Experiences of rural Bangladeshi women during the first postpartum months. International Journal of Qualitative Studies on Health and Well-being, 10, 1-9.

Emmanuel, E., Creedy, D., \& Fraser, J. (2001). What mothers want: a postnatal survey. Australian Journal of Midwifery, 14(4), 16-20.

Fishbein, E. G., \& Burggraf, E. (1997). Early postpartum discharge: how are mothers managing?. JOGNN Clinical Studies, 27(2), 142-148.

Hannan, J., Brooten, D., \& Youngblut, J. M. (2016). Comparing mothers' postpartum concerns in two clinical trials 18 years apart. Journal of the American Association of Nurse Practitioners, 28(11), 604-611.

Jansen, I., \& Stewart, M. (1990). Maternal concerns: what are they?. Can. Fam. Physician, 36(jun), 1103-1107.

Kaitz, M. (2007). Maternal concerns during early parenthood. Child: care, health and development, 33(6), 720-727.

Kanotra, S., D’Angelo, D., Phares, T. M., Morrow, B., Barfield, W. D., Lansky, A. (2007). Challenges faced by new mothers in the early postpartum period: An analysis of comment data from the 2000 Pregnancy Risk Assessment Monitoring System (PRAMS) Survey. Matern Child Health J., 11, 549558.

Liu, Y. Q., Petrini, M., \& Maloni, J. A. (2015). “Doing the month": postpartum practices in Chinese women. Nursing and Health Sciences, 17, 5-14.

Lugina, H. I., Christensson, K., Massawe, S., Nystrom, L., Lindmark, G. (2001). Change in maternal concerns during the 6 weeks postpartum period: a study of primiparous mothers in Dar Es Salaam, Tanzania. Journal of Midwifery \& Women's Health, 46(4), 248-257.

Lugina, H. I., Nystrom, L., Christensson, K., \& Lindmark, G. (2004). Assessing mothers' concerns in the postpartum period. Journal of Advanced Nursing, 48(3), 279-290.

Martin, A., Horowitz, C., Balbierz, A., \& Howell, E. A. (2014). Views of women and clinicians on postpartum preparation and recovery. Matern Child Health J., 18, 707-713.

Mendes, I. M. (2009). Ajustamento materno e paterno: experiências vivenciadas pelos pais no pós-parto. Coimbra: Mar da Palavra.

Mendes, K. D., Silveira, R. C. \& Galvão, C. M. (2008). Revisão integrativa: método de pesquisa para a incorporação de evidências na saúde e na enfermagem. Texto Contexto Enfermagem, 17(4), 758-764.

Ong, S. F., Chan, W. S., Chong, Y. S., Shorey, S., Klainin-Yobas, P., He, H. (2014). First-time mothers' postnatal experiences and support needs in Singapore: a descriptive qualitative study. Midwifery, 30(6), $772-$ 778.

Osman, H., Chaaya, M., Zein, L. M., Naassan, G., Wick, L. (2010). What do first-time mothers worry about? A study of usage patterns and content of calls made to a postpartum support telephone hotline. BMC Public Health, 10, 1-6.

Salonen, A. H., Oommen, H., \& Kaunonen, M. (2014). Primiparous and multiparous mothers' perceptions of social support from nursing professionals in postnatal wards. Midwifery, 30, 476-485.

Sheil, E. P., Bull, M.J., Moxon, B. E., Muehl, P. A., Kroening, K. L., Peterson-Palmberg, G., Kelber, S. (1995). Concerns of childbearing women: a Maternal Concerns Questionnaire as an assessment tool. JOGNN Clinical Studies, 24(2), 149-154.

Weiss, M., Fawcett, J., \& Abe, C. (2009). Adaptation, postpartum concerns, and learning needs in the first two weeks after caesarean birth. Journal of Clinical Nursing, 18, 2938-2948.

Winnicott, D. W. (2014). Primary Maternal Preoccupation [1956]. In D. W. Winnicott (Ed.), Through Paediatrics to Psychoanalysis: Collected Papers (pp. 300-305). New York, USA: Routledge. 